\title{
Saint-Domingue, Rights, and Empire
}

Between 1789 and 1804 black slaves and free men of colour transformed the French plantation colony of Saint-Domingue into the independent state of Haiti. What initially began as an attempt of white French planters seeking representation in the newly summoned Estates General and wealthy so-called gens de couleur (free men of colour) demanding an end to racial discrimination, turned into a full-blown revolution when a massive slave insurrection broke out in the summer of 1791. A bloody civil war racked the island for more than a decade. With French, Spanish, and English armies invading the island and thousands of refugees fleeing to other Caribbean islands and North America, the revolutionary events in Saint-Domingue soon acquired international dimensions. News of the island's 'disaster' travelled far and wide. What was perhaps most amazing to observers at the time, apart from the reported scenes of violence and atrocities of civil war, was the interaction between metropolitan France and her colony's inhabitants. In 1792, after some hesitant and contradictory measures, the French Legislative Assembly granted free men of colour full citizenship; two years later, on February 4, 1794, the National Convention ratified the emancipation of slaves into citizens of the French Republic. Ten years later, despite Napoleon Bonaparte's attempt to re-establish control over the colony and restore slavery by sending a massive military expedition force, an army of black and coloured revolutionaries founded the first black independent state in America. ${ }^{1}$

The succession of revolutionary events that has come to be known as the Haitian Revolution sent shockwaves throughout the Atlantic world. In the

1 The last two decades have seen an explosion of publications on the Haitian Revolution. For recent overviews, see L. Dubois, Avengers of the New World: The Story of the Haitian Revolution (Cambridge, MA: Belknap Press of Harvard University Press, 2004); D.P. Geggus and N. Fiering (eds.), The World of the Haitian Revolution (Bloomington, IN: Indiana University Press, 2009); D.P. Geggus, The Haitian Revolution. A Documentary History (Indianapolis, IN: Hackett Publishing, 2014); J.D. Popkin, A Concise History of the Haitian Revolution (Malden, MA: WileyBlackwell, 2012). The classic account is C.L.R. James, The BlackJacobins. Toussaint L'Ouverture and the San Domingo Revolution (London: Penguin, 2001 [1938]). Important recent French studies on the French Revolution and the colonies include: F. Gauthier, Laristocratie de l'épiderme: Le combat de la Société des Citoyens de Couleur, 1789-1791 (Paris: CNRs Éditions, 2007); J. Piquet, L'émancipation des noirs dans la Révolution française: 1789-1795 (Paris: Karthala, 2002); F. Regent, Esclavage, métissage, liberté. La Révolution française en Guadeloupe (Paris: Grasset, 2004); C. Wanquet, La France et la première abolition de l'esclavage, 1794-1802: Le cas des colonies orientales, Île de France (Maurice) et La Réunion (Paris: Karthala, 1998).

(C) RENÉ KOEKKOEK, 2020 | DOI:10.1163/9789004416451_004

This is an open access chapter distributed under the terms of the CC BY-NC 4.o licensené Koekkoek - 9789004416451 
course of events, as in its aftermath, the reactions to, and representations of the Haitian Revolution were diverse and ambiguous. The Haitian Revolution was, in the words of David Geggus, a combined outburst of 'free coloured activism, white settler autonomism, and slave resistance'. ${ }^{2}$ These various elements have come to function differently in different argumentative contexts. The following three chapters consist of a comparative analysis of the reactions to, and reflections on the different phases and events in Saint-Domingue in order to understand in what ways these responses came to inform conceptions of the limits of citizenship in France, the Dutch (Batavian) Republic and the United States. In what contexts and through what existing categories of thought were these disruptive events interpreted and explained at the time? In what kind of broader arguments concerning the nature and scope of citizenship did the Haitian Revolution come to play a role? And how did it affect the idea of a shared transatlantic revolutionary project of citizen emancipation?

Historians have rightly insisted that many aspects of the colonial revolutions in the Caribbean evolved from autonomous forces, that is, without France. The idea that there was an inevitable causal link between the 1789 Declaration of the Rights of Man and Citizen and the 1791 slave insurrection, or that the general emancipation degree of February 1794 was the unavoidable outcome of the slave insurrection has been forcefully challenged. ${ }^{3}$ Without doubt, both the insistence on causal factors independent of the metropole and the stress on the contingent nature of a number of crucial episodes have sharpened our grasp of the origins and nature of the Haitian Revolution and the contexts in which it took place. ${ }^{4}$ They are helpful reminders that the view of a francocentric unfolding of a universal rights project rooted in Enlightenment or 'radical' Enlightenment thought is overly simplistic. ${ }^{5}$

Yet it is at the same time crucial not to let the modern historian's perspective obscure our view of how contemporary observers perceived and interpreted the context and causal links between the French Revolution and the events in

2 D.P. Geggus, 'Saint Domingue on the Eve of Revolution', in: Geggus and Fiering (eds.) The World of the Haitian Revolution, pp. 3-20, at p. 14.

3 Popkin, You are all Free. Cf. D. Geggus, 'Rights, Resistance and Emancipation: A Response to Robin Blackburn', in: K.E. Tunstall (ed.) Self-Evident Truths? Human Rights and the Enlightenment (New York: Bloomsbury, 2012), pp. 157-167.

4 In particular James, The BlackJacobins; Césaire, Toussaint Louverture; Dubois, Avengers of the New World. Cf. D.P. Geggus, 'Racial Equality, Slavery, and Colonial Secession during the Constituent Assembly', American Historical Review 94 (1989), pp. 1290-1308, p. 1304.

5 The main representative of such views is probably N. Nesbitt, Universal Emancipation: The Haitian Revolution and the Radical Enlightenment (Charlottesville, VA: University of Virginia Press, 2008). For criticisms, see: D.P. Geggus, [review] N. Nisbett, 'Universal Emancipation: The Haitian Revolution and the Radical Enlightenment', American Historical Review 114 (2009), pp. 1501-1502. 
Saint-Domingue. Many commentators at the time perceived a direct link between the revolutionary decrees coming from the metropole and the unfolding catastrophic events in the French colony. The supposed causal link between French philosophical radicalism and the eruption of violence on SaintDomingue was widely established and articulated. What is striking, moreover, is that many of these writings did not pay any attention to the fact that the decision made in late 1793 by the leader of the Second Civil Commission to Saint-Domingue, Léger Félicité Sonthonax, to offer black slaves citizenship, was actually made under the severe pressure of the prospect of a military defeat against the British colonial armies. Few noticed that the French National Convention's ratification of February 4, 1794, was actually a confirmation of an established fact on the (Saint-Dominguan) ground. Finally, the anarchy, devastation, and horrors were often imputed to the French 1794 decision to abolish slavery, without seriously paying attention to the fact that a civil war had been going on since 1791. As a consequence, explanations for the catastrophic course of events in Saint-Domingue were more often than not reduced to a typical French zeal for radical egalitarian principles and their 'mistaken' application.

Various groups in the revolutionary Atlantic world welcomed or were (eventually) willing to defend the Saint-Domingue slave insurrection: enslaved and free blacks in the United States and the Caribbean, radical democraticrepublicans in the Batavian Republic, a number of (white) abolitionist activists in the United States, and some (but by no means all) radical Jacobins in revolutionary France. These groups were few, however, small in size, and hardly organized. Almost none supported the idea of immediate emancipation.

The majority of American, Dutch, and French revolutionaries, politicians, journalists, and publicists who reflected upon the events on Saint-Domingue expressed their views on citizenship on two levels. On the one hand, they qualified the nature and scope of citizenship in terms of the alleged backward level of civilization of black slaves. Here we can see striking commonalities between American, Dutch, and French evaluations of the Haitian Revolution, and parallel justifications of the limitations that were placed on the scope of citizenship. This civilizational qualification of citizenship led some to propose a status of 'second class' citizenship (although this specific term was not used). Various educational 'regeneration' programs - with varying time spans - were designed and aimed at educating and enlightening what they thought were 'infantile' savages. Others suggested more permanent schemes of civilizational inequality and civic exclusion. In either case, Saint-Domingue was invoked as the decisive proof that black slaves were insufficiently enlightened and civilized to be emancipated into citizens.

On the other hand, the French wavering and sometimes contradictory policies toward Saint-Domingue, in particular the decision to attribute to former 
black slaves citizenship rights in 1794, was widely seen as a dangerous philosophical experiment, as evidence that the French Revolution had careered off track. The French decree of immediate emancipation incited many Dutchmen and Americans, as well as more conservative Frenchmen around 180o, to disassociate themselves from French 'universalistic' understandings of citizenship that were considered dangerously naïve and utopian. The Haitian Revolution, thus, prompted people on both sides of the Atlantic to (re-)articulate the limits of their models of citizenship and disassociate themselves from an Atlantic citizenship discourse once shared. The Haitian Revolution, as it was seen through the lens of the civic policies of revolutionary France led to a divergence of citizenship discourses in the Atlantic world.

The following chapters will analyse this process in three phases. Focusing on the period between roughly mid-1789 to the summer of 1791 , this chapter shows how the question of equal citizenship within the framework of a colonial empire and beyond colour lines was put on the revolutionary agenda. This was by no means self-evident. The issue of civic equality and representation was raised first by French white planters. The claims of free people of colour both on the island and in France for equal rights and citizenship raised the stakes dramatically, especially when prominent revolutionaries of the Société des Amis des Noirs joined their ranks. They invoked the revolutionary 'logic' of the declarations of the rights of man and equal citizenship and applied it to the realm of the colonial empire. As both supporters and opponents of the claims by free people of colour understood, the situation on Saint-Domingue was now indissolubly related to wider debates about the ideals of the age of revolution, the constitutional unity of the empire, and the new revolutionary principles underlying citizenship. Chapter 3 goes on to show how the picture of SaintDomingue drastically altered between the outbreak of the slave insurrection in August 1791 and the French National Convention's emancipation decree of February 1794. It focuses on the articulation of imperial civic hierarchies based on the insurrectionists' alleged level of civilization. Chapter 4 shows how in the second half of the 1790 s the French imperial policies regarding Saint-Domingue became synonymous with what was considered a dangerous form of Jacobin universalism, a 'French' revolutionary radicalism that had gone astray.

The Haitian Revolution forced Americans, Dutch and French revolutionaries to reflect anew on the scope of revolutionary citizenship and the core, often implicit, assumptions underlying it. As Lynn Hunt has recently pointed out, the 'act' of declaring the rights of man, either in the 1776 American Declaration 
of Independence, the 1789 French Déclaration des droits de l'homme et du citoyen, or the 1795 Dutch Verklaring der rechten van den mensch en den burger brought about a certain 'inner logic'. Once the universal rights of humanity were declared, so the reasoning behind this logic goes, 'the floodgates were open': religious minorities, free people of colour, Jews, women, all could now claim equal rights on the basis of their membership of the party of humanity. ${ }^{6}$ The generality of the declarations' wordings - 'man', 'humanity', 'citizen' - 'exceeded the act of its enunciation', as Étienne Balibar has put it. ${ }^{7}$ It provoked radical interpretations of equality that the original drafters might not have imagined and most of them did not conceive at all. ${ }^{8}$ In contrast to Hunt, however, I prefer to speak of 'rights of man' instead of 'human rights' (as most eighteenth-century authors themselves actually did). Late eighteenth-century rights declarations were not intended to trump the ultimate authority and territorial integrity of the nation-state, as in modern human rights discourse, but rather to serve as its foundation by proclaiming the sovereignty of a distinct people. ${ }^{9}$ The rights of man only acquired meaning in a constituted political space. A key issue for colonial empires such as France and the Dutch Republic was how to define and demarcate 'the people' within what Gary Wilder has called an 'imperial nation-state.' ${ }^{0}$

Moreover, as Samuel Moyn has argued, there are reasons to be sceptical about how exactly the mechanism of the 'universalization' of rights works, since ascribing a universal logic to rights seems to presuppose that rights are necessarily univeralizable independent of human agency. ${ }^{11}$ In my view, it would be more accurate to qualify the notion of 'inner logic': rights declarations brought about an awareness of the argumentative or conceptual force of the potentially universal logic of rights declarations that, after all, were written in a highly universalistic language.

6 Hunt, Inventing Human Rights, pp. 146-176, esp. pp. 148-153.

7 E. Balibar, 'Citizen Subject', in: E. Cadava, P. Connor, and J. Nancy (eds.) Who Comes After the Subject? (London: Routledge, 1991), pp. 33-57, at p. $5^{2}$.

8 A.G. Sepinwall, The Abbé Grégoire and the French Revolution. The Making of Modern Universalism (Berkeley, CA: University of California Press, 2005), pp. 90-91; K.M. Baker, 'The Idea of a Declaration of Rights', in: D. van Kley (ed.) The French Idea of Freedom. The Old Regime and the Declaration of Rights of 1789 (Stanford, CA: Stanford University Press, 1994), pp. 154-196, at pp. 156-157, 191; M. Gauchet, 'Rights of Man', in: Ozouf and Furet (eds.) A Critical Dictionary of the French Revolution, pp. 818-828.

9 Cf. S. Moyn, The Last Utopia: Human Rights in History (Cambridge, MA: Belknap Press of Harvard University Press, 2010). See however, Edelstein, 'Enlightenment Rights Talk'.

10 Wilder, The French Imperial Nation-State.

11 S. Moyn, 'On the Nonglobalization of Ideas', in: S. Moyn and A. Sartori (eds.) Global Intellectual History (New York, N.Y.: Columbia University Press, 2013), pp. 187-204. 
Illustrative of the awareness of this logic - and the subsequent reticence on the part of many revolutionaries to face the potentially radical implications of the universalistic logic of rights declarations - is the often-reprinted series of articles 'The Rights of Black Men' by the Connecticut republican publicist Abraham Bishop. In September 1791, he deliberately invoked American revolutionary language so as to cast a sympathetic light on the slave revolt in SaintDomingue. He urged his readership to recognize that Saint-Dominguan blacks were fighting 'a cause like ours'. Hence, he commended, '[l]et us be consistent Americans'. A radical follower of Thomas Paine, Bishop reckoned that this 'seems to be the moment for the liberating societies in Europe and America to come forward, and to shew the sincerity of their professions, and their unwavering attachment to the Rights of Man'. His assertion that Saint-Dominguan slaves are 'entitled to freedom' was 'founded on the American Declaration of Independence $[\ldots]$ for we did not say, all white men are free, but all men are free.'12

That the claims of particular groups were seen as following a more general logic can also be observed in a lengthy pamphlet published in 1792 entitled Régénération des colonies by the lawyer, judge, member of the Société des Amis des Noirs, and future member of the National Convention and deputy of the Council of Five Hundred, Antoine-Jean-Thomas Bonnemain. In defence of the decree of April 4, 1792, that ensured civil and political equality to free people of colour, Bonnemain suggested that this decree 'should be considered like those regarding the Protestants and the Jews, decrees that are [...] a consequence of the natural and civil rights of man, guaranteed by the constitution.'. ${ }^{13}$ Another five years later, the remarks put forth by the Dutch representative Herman Hendrik Vitringa in the National Assembly of the Batavian Republic in the spring of 1797 conveyed a similar way of reasoning. During a series of debates

12 'The Rights of Black Men' appeared for the first time in Columbian Centinel (Boston, Massachusetts), September 21, 1791. It was reprinted in The Argus (Boston, Massachusetts), November 22, 25, December 2, 1791; Cumberland Gazette (Falmouth, Massachusetts), December 5 and 12, 1791; Federal Gazette (Philadelphia, Pennsylvania), December 3, 7, 17, 1791, American Museum (magazine), November 12, 1792, and National Gazette (Philadelphia, Pennsylvania), July 31, 1793. See T. Matthewson, 'Abraham Bishop, "The Rights of Black Men”, and the American Reaction to the Haitian Revolution', The Journal of Negro History 67 (1982), pp. 148-154; Cotlar, Tom Paine's America, pp. 58-59; M.A. Grossbart, 'Abraham Bishop: Teacher, Lawyer, Orator, and Politician', in: M.A. Morrison (ed.) The Human Tradition in Antebellum America (Lanham, MD: Rowman \& Littlefield, 200o), pp. 1-18; White, Encountering Revolution, p. 137. Quotes are taken from: Matthewson, 'Abraham Bishop', pp. $150-153$.

13 A.-J.-T. Bonnemain, Régénération des colonies, ou moyens de restituer graduellement aux hommes leur état politique et d'assurer la prospérité des nations (Paris: Imprimerie du Cercle Social, 1792), p. 101. 
over the question whether a new constitution should decree the abolition of slavery and the slave trade, Vitringa contemplated that because of the proclamation's 'abstract principles [...] we are no longer able to give or take from the eternal right of nature.' 'It could very well happen', he asserted, implicitly but obviously referring to Saint-Domingue, that 'only afterwards one comprehends the dangerous implications or the inapplicability' of such general principles. ${ }^{14}$

Regardless of the question whether and how many Atlantic revolutionaries actually subscribed to universalistic readings of declarations of rights of man, the remarks of these politicians and publicists demonstrate that on both sides of the Atlantic there was an awareness and public recognition of the argumentative or conceptual force of the logic of universalistic rights declarations. What this logic and the claims that drew upon it also generated, however, was the mobilization and sophistication of an arsenal of concepts, arguments, and theories to postpone, circumvent or simply refute this logic. The international reactions to the Haitian Revolution represent a pivotal moment in this process. It incited the articulation of deeply rooted assumptions about the prerequisites and capacities individuals needed in order to be admitted to the political community of citizens.

\section{The Nation's Colonial Citizens}

Soon upon hearing rumours of Louis XVI convoking the Estates General in 1787-1788, French white planters in Saint-Domingue illegally established electoral committees in order to delegate representatives to the general meeting of the realm's estates, which by the time they arrived had turned into the National Assembly. The French overseas colonial empire of the second half of the eighteenth century was an empire in decline, but Saint-Domingue was booming. France's loss of the Seven Year's War of $175^{-1763}$ against the British had severely reduced her overseas possessions. The French were forced to renounce all their claims to Canada and had lost all but a handful of small plantation colonies and trading posts in the Indian Ocean. Their only and most lucrative remaining colonies were those in the Caribbean, Saint-Domingue standing out as the 'jewel in the crown'. ${ }^{15}$

14 Dagverhaal 5, no. 493, 28 April 1797 (session April 22), pp. 731-732; Dagverhaal 6, no. 549, 3 June 1797 (session May 22), p. 17. Vitringa was a member of the commission chaired by Jacob Hendrik Floh ('Floh commission') instituted by the Batavian National Assembly to give advice about the section on colonies in the future Batavian constitution.

15 The islands in the Indian Ocean were Île-de-France (now Mauritius) and Île Bourbon (now La Réunion), both near the east coast of Madagascar. 
Saint-Domingue was nothing less than a goldmine for the French colonial economy. More sugar came from Saint-Domingue than from all English colonies combined. The capital Cap Français, a city with more inhabitants than Philadelphia, was a burgeoning city with a Société royale des sciences et arts, literary societies and reading rooms, markets, bathhouses, theatres, and botanical gardens. It was a crucial nub in Caribbean trade networks. French overseas trade with Saint-Domingue comprised one-third of France's overall colonial economy. The sugar and coffee production of Saint-Domingue made up 40 and 60 percent of Europe's total consumption, respectively. SaintDomingue, in short, was of major commercial interest to France, especially to major port cities such as Bordeaux, Nantes, Marseilles, and Le Havre whose economies thrived on colonial trade.

On the eve of the French Revolution, both the ruling plantation class in Saint-Domingue and colonial landowners residing in France had their complaints about the French monarchy's imperial policy. Wealthy French planters and merchants living in Saint-Domingue decried the mercantilist restrictions imposed by the Colonial Ministry in Paris, and, moreover, resented the 17841785 royal decrees to ameliorate the condition of plantation slaves. ${ }^{16}$ Poor whites who did not belong to the wealthy planter class - among them plantation employees, seamen, artisans, guards, shopkeepers, sometimes called petit blancs - also had their grievances; against rich planters for not allowing them to set up their own plantations and share in their wealth; against the colony's royal government for reasons similar to those of the wealthy planter class; and in particular against wealthy free people of colour, several hundreds of families of whom owned slave plantations themselves, and whose social standing aroused a mixture of frustration, racial prejudice and envy. ${ }^{17}$ Finally, 'absent' plantation owners living in France, although supportive of more laissez-faire trade laws, feared that granting too much autonomy to the colonists might be harmful to their interests. American independence had set an unprecedented and forceful example of what conflicts of interests between metropole and colony could ultimately lead to. For many Frenchmen, the anti-imperial American Revolution was still fresh on their mind.

Not surprisingly, revolutionary white Saint-Dominguans reminded Americans of their own revolution too. A striking account of the early revolutionary

16 L. Dubois and J.D. Garrigus, Slave Revolution in the Caribbean, 1789-1804: A Brief History with Documents (Basingstoke: Palgrave Macmillan, 2006), pp. 16-19; M.W. Ghachem, The Old Regime and the Haitian Revolution (Cambridge: Cambridge University Press, 2012), pp. $156-166$.

17 Dubois and Garrigus, Slave Revolution in the Caribbean, pp. 20-21; Geggus, 'Saint Domingue on the Eve of Revolution', pp. 12-13; James, The Black Jacobins, p. 27. 
spirit among radicalized white settlers in light of the spectre of colonial independence can be found in the observations of Nathaniel Cutting (d. 1822). A New England businessman, slave trader as well as U.S. consul in Cap Français, Cutting wrote a number of letters from Saint-Domingue to his good acquaintance Thomas Jefferson, then US Secretary of State. ${ }^{18}$ In a letter dated 6 July 1790 from St. Marc, a west-coast town where radical whites had formed a colonial assembly, Cutting welcomed what he saw as the sudden and unexpected emancipation of French colonists 'from the galling fetters of a despotic Government'. ${ }^{19}$ Coming from the French seaport Le Havre where Cutting had lived and worked for three years between 1786 and the late summer of 1789 , he immediately related the turmoil in Saint-Domingue to the revolutionary happenings he had witnessed in Paris. Born and raised in revolutionary Massachusetts, Cutting was, thus, in the unique position to have personally witnessed three late eighteenth-century revolutions. Like most of his fellow Americans who, irrespective of their political colour, had delighted in the outbreak and early phase of the revolution on the other side of the Atlantic, Cutting rejoiced at the idea that the French Revolution, as he put it, 'may date its conception' from 'the late glorious struggle for Liberty' in America. ${ }^{20}$ 'Soon after the Commencement of the late Revolution in France', Cutting reported to Jefferson, 'the French Inhabitants of this Island became sensible of their consequence and determin'd to assert the natural rights of men'. Although weary of the 'Anarchy' that already had begun to 'unfurl her hateful Banner' as a consequence of the French colonists' differences in 'Political Sentiments', Cutting seemed to recognize their 'patriotic motive of securing to the Inhabitants of this Colony and their Posterity the blessings of a liberal constitution. ${ }^{21}$ Encouraged by Jefferson's assurance that the State Department relied heavily on the information contained in his letters which were regularly communicated to President Washington, Cutting even pictured to Jefferson a future in which the colony

18 For biographical information on Cutting, see Mr. Frothingham and Dr. Ellis, 'Extracts from Diary of Nathaniel Cutting', Proceedings of the Massachusetts Historical Society 12 (18711873), pp. 57-67, p. 6 o.

19 Nathaniel Cutting to Thomas Jefferson, 6 July 1790, The Papers of Thomas Jefferson Digital Edition, ed. B.B. Oberg and J.J. Looney (Charlottesville, VA: University of Virginia Press, Rotunda, 2008), http://rotunda.upress.virginia.edu/founders/TSJN-01-17-02-0002 (accessed 13 Nov 2012) [hereafter: $P T J$ ].

20 Nathaniel Cutting to Harrison Gray Otis, August 1789, Letterbook I, p. 71, in: Nathaniel Cutting Papers, Massachusetts Historical Society, as cited in: S.P. Newman, 'American Political Culture and the French and Haitian Revolutions. Nathaniel Cutting and the Jeffersonian Republicans', in: D.P. Geggus (ed.) The Impact of the Haitian Revolution in the Atlantic World (Columbia, S.C.: University of South Carolina Press, 2001), pp. 72-89, at p. 74. Cutting to Jefferson, 6 July 1790, PTJ; Cutting to Jefferson, 4 August 1790, PTJ. 
of Saint-Domingue 'may possibly fall within the Jurisdiction of the Thirteen United States' or at least 'will mutually invigorate those principles of Constitutional Freedom which have apparently taken such deep root in both Countries.'.22

Cutting's initial exultation about the prospect of a second independent New World republic in the Summer of 1790 was, however, rather optimistic at the time. A considerable part of the Saint-Dominguan plantations was owned by planters who had their permanent residence in France and were obviously not in favour of the colony's secession. For most white colonists residing in SaintDomingue who longed for more autonomy and self-governance, outright secession was not particularly desirable either, as they were being outnumbered by the slave population by 1 to 17 . They would have to invoke the support of French troops in case of an emergency, not to mention the danger of foreign invasion in a Caribbean environment occupied by increasingly hostile imperial powers. It was only from early 1791 onwards that threats of independence became more outspoken and widespread. ${ }^{23}$

Although Cutting's cautious suggestion of a second colonial revolution in the America's may not be surprising from an American perspective, revolutionary Saint-Domingue of $1789-90$ differed in at least one crucial aspect from the revolutionary American colonies of the 1770s: whereas Americans equated revolution with colonial independence, now the imperial motherland itself was undergoing a revolution. Revolutionary Saint-Domingue questioned and destabilized the limits of the sovereignty of the revolutionary French state, especially since the Declaration of the Rights of Man and Citizen had relocated this sovereignty within the nation. Whereas the American Revolution had established a close link between consent, citizenship and national selfdetermination, creating outside the boundaries of the British Empire a new polity on the basis of the - at least in theory - voluntary consent of its citizens, this spectre of colonial secession and its impact on the reconfiguration of the notion of citizenship within a 'republican empire' would work out differently in the case of French Saint-Domingue, and eventually the Dutch colonies. ${ }^{24}$ The French and Dutch 'imperial revolutions' did not imply a shift from overseas empire to nation-state. It involved, as Jeremy Adelman has argued, 'the exploration of models of re-accommodating colonies into imperial formations $[\ldots]$ that would stabilize, not dissolve, regimes. ${ }^{25}$

\footnotetext{
22 Jefferson to Cutting, 26 November 1790, PTJ; Cutting to Jefferson, 19 April 1791, PTJ.

23 Dubois, Avengers of the New World, pp. 89-90.

24 Kettner, The Development of American Citizenship, pp. 173-209.

25 Adelman, 'An Age of Imperial Revolutions', p. 332.
} 
Ironically, Saint-Dominguan planters partially called down catastrophe on themselves. By claiming to be part of the nation, and thus being entitled to representation in the metropole, they (perhaps unintentionally) raised the question of the constitutional unity of the French empire. As soon as the delegation of representatives of white Saint-Dominguan planters arrived in Paris and requested admission to the Estates General, their status became fiercely contested. In 1789, the island's population consisted of about 30,000 whites, 25,000 to 30,000 free people of colour, and around 500,000 black slaves of whom up to two-thirds were born in Africa. The colonial representatives requested a number of seats in the Estates General in proportion to the colony's entire population, but in late June and early July 1789 this request was criticized, most resolutely by the leading revolutionary Honoré Gabriel Riqueti, comte de Mirabeau. 'Do the colonies claim that they regard their negroes and people of colour as belonging to the category of men or to that of beasts of burden?' he asked. He went on to point out that the 'free people of colour are proprietors and tax-payers', implying that they were entitled to full citizenship rights, 'yet they have not been allowed to vote'. Mirabeau insisted that if 'the colonists mean to consider the Negroes and the people of colour as men, let them free the former; let them give them the right to vote and to be elected'. Carrying the colonists' reasoning to the absurd, Mirabeau concluded by reminding them that 'in setting the number of deputies in proportion to the population of France, we have not taken into consideration the number of our horses or our mules.' ${ }^{26}$

In an address to the National Assembly on October 22, 1789, drawn up by a meeting of people of colour living in Paris, the charge of inconsistency was reiterated. They advanced the assumption of the legal unity of the French empire and referred directly to the Declaration of the Rights of Man and Citizen that had been proclaimed only a few months earlier on August 26, $1789 .{ }^{27}$ The 'unfortunate American colonists known in the islands under the name of mulattoes, quadroons, etc.', the address stated, claim their 'inalienable rights [...], those rights that you have solemnly recognized and so faithfully established when you established as the foundation of the constitution "that all men are born and remain free and equal in rights"'. 28

$26 \quad A P 8$, p. 186.

27 On the free people of colour in Saint-Domingue and France, see D. Garrigus, Before Haiti: Race and Citizenship in French Saint-Domingue (Basingstoke: Palgrave Macmillan, 2006); Gauthier, L'Aristocratie de l'épiderme, but see Jeremy Popkin's critical review of Gauthier's book on H-France Review 9 (2009), No. 3 .

28 'Discours de M. Joly au nom d'une députation des hommes de couleur', 22 Octobre 1789, $A P$ 9, p. 482. Translation taken from Dubois and Garrigus, Slave Revolution in the Caribbean, pp. 68-69. 
Their address was part of a broader campaign for civic and political equality for gens de colour led by wealthy coloured planters Julien Raimond and Vincent Ogé, who presented themselves in Paris as 'colons américains'. Between 1789 and 1793 Raimond would write a number of notable pamphlets and become a respected as well as despised voice on colonial matters. ${ }^{29}$ Through his efforts, the cause of Saint-Dominguan free people of colour was quickly embraced by the Société des Amis des Noirs. This Paris-based antislavery society, founded in February 1788 by Jacques-Pierre Brissot, included prominent revolutionaries such as Condorcet, Lafayette, Mirabeau and the Abbé Grégoire. ${ }^{30}$ Initially members of the Société des Amis des Noirs were hardly concerned with free people of colour. ${ }^{31}$ The society's declared purpose was to bring an end to the slave trade and in its wake the gradual abolition of the institution of slavery. ${ }^{32}$ Until early 1789, the Abbé Grégoire was hardly even interested in colonial affairs and ridiculed those who reserved their charity and generosity for people 'two thousand leagues distant. ${ }^{33}$ Raimond, on the other hand, a plantation slaveholder himself, was primarily concerned with the civil emancipation of the free coloured population and only in a later stage occasionally advocated the gradual emancipation of black slaves.

During the first two years of the revolution, the French proslavery lobby, a powerful, well-connected, and wealthy group of men, was highly successful in thwarting the attempts of the Société des Amis des Noirs to place the ending of

29 Julien Raimond's most important publications include Observations adressées à l'Assemblée Nationale par un député des colons américains (n.p., 1789); idem, Observations sur l'origine et les progrès du préjugé des colons blancs contre les hommes de couleur (Paris: Belin, 1791); idem, Réflexions sur les véritables causes des troubles et des désastres de nos colonies (Paris, 1793). On Raimond, J.D. Garrigus, 'Opportunist or Patriot? Julien Raimond (1744-1801) and the Haitian Revolution', Slavery \& Abolition 28 (2007), pp. 1-21.

30 J.D. Popkin, You Are All Free: The Haitian Revolution and the Abolition of Slavery (Cambridge: Cambridge University Press, 2010), pp. 34-36. For the Société des Amis des Noirs, see M. Dorigny and B. Gainot, La Société des amis des Noirs, 1788-1799: Contribution à l'histoire de l'abolition de l'esclavage (Paris: Editions UnesCo, 2006), and D.P. Resnick, 'The Société des Amis des Noirs and the Abolition of Slavery', French Historical Studies 7 (1972), pp. $55^{8-569}$.

31 The founding statement of the society did not mention free people of colour: J.-P. Brissot, Discours sur la nécessité d'établir à Paris une société pour concourir, avec celles d'Amérique \& de Londres, à l'abolition de la traite \& de l'esclavage des nègres (Paris: n.p., 1788).

32 Condorcet, 'Règlement de la Société des amis des noirs' (1788), included in Condorcet, Political Writings ed. S. Lukes and N. Urbinati (Cambridge: Cambridge University Press, 2013), pp. 148-155.

33 H. Grégoire, Essai sur la régénération physique, morale et politique des Juifs (Paris: Éditions du Boucher, 2002 [1789]), p. 109. Cf. M. Dorigny, 'Grégoire et le combat contre l'esclavage pendant la Révolution', in: M. Dorigny and Y. Bénot (eds.) Grégoire et la cause des noirs (1789-1831). Combats et projets (Paris: Société française d'histoire d'Outre-mer, 2005), pp. $51-68$. 
the slave trade on the political agenda at all. As a consequence, members of the Société reckoned it a more efficient strategy to redirect their priorities and embrace with considerable enthusiasm the cause of free people of colour, at least for the moment. Their claim for equal French citizenship had come to be seen as a noble aspiration in itself. ${ }^{34}$

\section{Slavery and Civic Inequality in the US before Saint-Domingue}

The early efforts of the Saint-Dominguan gens de couleur demanding civic equality aroused various and opposite feelings in different parts of the United States. Structural differences ought to be kept in mind when considering reactions in France, the Dutch Republic, and the United States to the different phases of the Haitian Revolution. Whereas France and the Dutch Republic during the 1790 secame remodelled as overseas republican colonial empires, the newly independent United States had no distant colonies. But they were an expanding continental empire, that is, into the North American continent. ${ }^{35}$ During this period, the North American continent was not a 'blank slate' but a battleground for 'interimperial competition'.36 As John Craig Hammond has suggested, the growth and expansion of an 'empire of slavery' in late eighteenth and early nineteenth-century Ohio, Missouri and the Mississippi Valleys, where the gradual extension of American sovereignty went hand in hand with the protection of the slave system, was not a sharp break with the past but

34 J. Popkin, 'The French Revolution's Other Island', in: Geggus and Fiering (eds.) The World of the Haitian Revolution, pp. 199-222, at pp. 203-204.

35 E.H. Gould, Among the Powers of the Earth: The American Revolution and the Making of a New World Empire (Cambridge, MA: Harvard University Press, 2012); E.H. Gould and P.S. Onuf (eds.) Empire and Nation: The American Revolution in the Atlantic World (Baltimore, MD: Johns Hopkins University Press, 2005); E. Hinderaker, Elusive Empires: Constructing Colonialism in the Ohio Valley, 1673-1800 (Cambridge: Cambridge University Press, 1997); P.J. Kastor and F. Weil (eds.), Empires of the Imagination: Transatlantic Histories of the Louisiana Purchase (Charlottesville, VA: University of Virginia Press, 2009); P.S. Onuf, Jefferson's Empire: The Language of American Nationhood (Charlottesville, VA: University Press of Virginia, 2000); A. Rothman, Slave Country: American Expansion and the Origins of the Deep South (Cambridge, MA: Harvard University Press, 2005); A. Taylor, The Divided Ground: Indians, Settlers, and the Northern Borderland of the American Revolution (New York: Alfred A. Knopf, 2006); R. White, The Middle Ground: Indians, Empires and Republics in the Great Lakes Region, 1650-1815 (Cambridge: Cambridge University Press, 1991).

36 J. Burbank and F. Cooper, Empires in World History: Power and the Politics of Difference (Princeton, N.J.: Princeton University Press, 2010), pp. 252, 26o; J.C. Hammond, 'Slavery, Settlement, and Empire: The Expansion and Growth of Slavery in the Interior of the North American Continent, 1770-1820', Journal of the Early Republic 32 (2012), pp. 175-206. 
rather a continuation of the practices of the Caribbean and North American British, French and Spanish empires. These regions in the North American interior were closely related to the greater Caribbean plantation world through commercial connections, trade networks (including slave networks), personnel, migration, and culture. Indeed, as Hammond puts it: 'In the history of empires and slavery in the North American interior, the ultimate exclusion of slavery from the old Northwest was exceptional', not the slave based American imperial expansion in the South and Mid-West. ${ }^{37}$

While in the Dutch and French empires slavery existed only in their distant colonies, in the social fabric and political culture of the American republic black slavery was a central domestic element, although varying from state to state. In 1790 the United States counted around 700,00o black slaves and 60,000 free blacks on a total population of 3.9 million people..$^{38}$ Ninety percent of the enslaved black population lived in the southern states. ${ }^{39} \mathrm{New}$ states that joined the Union in the 179os, such as Kentucky (1792) and Tennessee (1796), became slave states with slave laws modelled on those of North Carolina and Virginia. In the North, in contrast, Vermont had abolished slavery in 1777. Gradual abolition laws were adopted in Pennsylvania (1780), Connecticut and Rhode Island (both 1784), and New York (1799). New Jersey followed in 1804. Massachusetts never formally abolished slavery until 1865 , but judicial decisions were made against slavery during the $1790 \mathrm{~s}$. By 1800 , slavery was almost extinct in the northern states. Whereas in France and the Dutch Republic slavery and the presence in society of black and coloured peoples as such, was a distant, colonial affair, Americans struggled with the question how to forge a multiracial republic. The issue of slavery and abolition was a much more contentious and politicized domestic issue in the early American republic than in either France or the Dutch Republic.

Abolitionist and manumission societies had been founded in Philadelphia (Pennsylvania Abolition Society) and New York (New York Manumission Society) as early as 1775 . Other societies were formed in Delaware, Rhode Island, Maryland, Connecticut, and Virginia. ${ }^{40}$ Some of them were joined by influential

37 Hammond, 'Slavery, Settlement, and Empire', p. 203.

38 Between 1790 and 1820 the free black population increased from nearly 6o,0oo to over 230,000 in 1820 . At the same time, the total number of slaves rose by nearly three quarters.

39 M.I. Lowance, Jr. (ed.) A House Divided. The Antebellum Slavery Debates in America, $1776-$ 1865 (Princeton, N.J.: Princeton University Press, 2003), pp. 5-6. Philadelphia in particular was known for its large free black population (around 1,800 in 1790).

40 The full name of the Pennsylvania Abolition Society, founded by a group of Philadelphia Quakers, was 'Pennsylvania Society for Promoting the Abolition of Slavery and the Relief 
founding fathers. Several east coast cities had considerable free black communities who founded their own abolitionist societies. Most prominent among them was the Free African Society founded in 1786 in Philadelphia, the city with the greatest free black population (around 6.00o). The societies were heavily criticized by spokesmen of white southern planters. Slavery increasingly became a sectional issue, with slaveholding southern states where abolitionism was marginal and almost slave-free northern states.

Although during the 1780 s and 1790 s slavery merely vanished in the northern states, none granted free blacks full citizenship. Freedom from slavery, as free black Americans became all too aware, was not the same thing as equal citizenship. In the immediate aftermath of the ratification of the constitution in 1789 , free black people were allowed to vote in a number of northern states. But between 1790 and 1835 the voting rights of free black people - as well as numerous other fundamental rights - actually became more restricted in virtually all states. The citizenship that free black Americans did enjoy for a while, and only in some states, was second-class citizenship at best. For blacks in the north, freedom came by degrees, civic inequality in rights and liberties was a permanent fact of life. ${ }^{41}$

On a Federal level, the Constitution of 1789 had fully acknowledged the existence of slavery by adopting the so-called 'three-fifth compromise' which stipulated that black slaves who under state laws were officially the owner's property and not allowed to vote, were counted for three-fifth in determining a state's total population, which in turn determined the apportioning of representatives, presidential electors, and direct taxes. ${ }^{42}$ The Naturalization Act of

of Free Negroes Unlawfully held in Bondage'. The Society was joined by influential revolutionaries such as Benjamin Rush. Benjamin Franklin was chosen as President in 1787. The New York Manumission Society counted prominent statesmen such as John Jay and Alexander Hamilton among its members. See J.R. Oldfield, Transatlantic Abolitionism in the Age of Revolution. An International History of Anti-Slavery, c. 1787-1820 (Cambridge: Cambridge University Press, 2013), pp. 15-23.

41 Free blacks could vote for a while in North Carolina, New York, New Jersey, Pennsylvania, Massachusetts, Rhode Island, New Hampshire, Delaware, Maryland, and Vermont. Bradburn. Bradburn, The Citizenship Revolution, pp. 262-271; R. Horsman, The New Republic. The United States of America, 1789-1815 (London: Longman, 2000), pp. 149-150. On abolition and emancipation in the northern states in the late eighteenth century, see G.B. Nash and J.R. Soderlund, Freedom by Degrees: Emancipation in Pennsylvania and its Aftermath (New York: Oxford University Press, 1991); J.W. Sweet, Bodies Politic: Negotiating Race in the American North, 1730-1830 (Baltimore, MD: Johns Hopkins University Press, 2003); S. White, Somewhat more Independent: The End of Slavery in New York City, 1770-1810 (Athens, GA: University of Georgia Press, 1991).

42 The relationship between the American constitution and slavery is still a topic of heated debates. See S. Wilentz, 'Constitutionally, Slavery Is No National Institution', New York 
1790, as well as the Militia Act of 1792 (providing for the organization of state militias) explicitly excluded black people, although the federal government did extend citizenship certificates to sailors of all races. ${ }^{43}$ In February 1793, moreover, Congress adopted the controversial Fugitive Slave Law which allowed local authorities to arrest and return runaway slaves, a measure decried by northern abolitionists and free blacks. In sum, over the course of the 179os, the Federal government furthered the interests of the slaveholding South, did little to fight slavery, and on the whole rejected the idea of equal citizenship for enslaved and free blacks alike.

If the struggle for emancipation by enslaved and free black people, as well as white abolitionists, neither stopped the expansion of slavery in the South nor led to full civic equality in non-slaveholding states, it nonetheless did put the very idea of slavery and civic inequality on the defensive. ${ }^{44}$ Thomas Jefferson's infamous suggestion in his Notes on the State of Virginia (1785) that black people belonged to another race which had certain innate inferior physical, mental, and moral characteristics, was not widely shared. More prevalent was the view, especially among those who considered themselves 'enlightened' Americans, that the experience of slavery as such had degraded the enslaved to an inferior status. Antislavery advocates, from the French-born Philadelphian Quaker Anthony Benezet to the revolutionary and physician Benjamin Rush, to the College of New Jersey professor Samuel Stanhope Smith rejected slavery. But they also rejected the immediate emancipation of black slaves into citizens. They all believed that enslaved and freed blacks were inferior to whites. In Nicholas Guyatt's summary: 'Temporarily and reversibly inferior, perhaps, and degraded through no fault of their own, but inferior nonetheless.' 45

During the 1780 s and 1790 s, (white) initiatives and plans for 'gradual' emancipation, educational programs, and children's schooling, often remained on

Times, September 16, 2015; L. Goldstone, 'Constitutionally, Slavery Is Indeed a National Institution', New Republic, September 17, 2015; D. Waldstreicher, 'How the Constitution Was Indeed Pro-Slavery', The Atlantic, September 19, 2015. More generally, see D. Waldstreicher, Slavery's Constitution. From Revolution to Ratification (New York: Hill and Wang, 2009).

43 N. Perl-Rosenthal, Citizen Sailors. Becoming American in the Age of Revolution (Cambridge, MA: Harvard University Press, 2015).

44 Cf. M. Mason, 'Necessary but Not sufficient. Revolutionary Ideology and Antislavery Action in the Early Republic', in: J.C. Hammond and M. Mason (eds.) The Politics of Bondage and Freedom in the New American Nation (Charlottesville, VA: University of Virginia Press, 2011), 11-31.

45 N. Guyatt, Bind Us Apart: How Enlightened Americans Invented Racial Segregation (Oxford: Oxford University Press, 2016), p. 38. 
the drawing board. ${ }^{46}$ Most important to their own emancipation were blacks themselves. Plans for wide-scale deportation of the black population to black colonies were envisioned by those who simply could not imagine, and would never accept living on an equal footing with a majority of free black people. But these plans never materialized during this period. ${ }^{47}$ When news from Saint-Domingue reached the shores of the United States, public opinion on slavery and the civic status of the free black population was a sectionally divisive and a politically sensitive issue. But on the level of the Federal government there was a consensus that the south could continue and expand their 'peculiar institution'.

Although Americans through their own revolution had become familiar with the logic of rights talk, the French revolution and Saint-Domingue re-ignited this discourse but in an even more universalistic key. The New-York Daily Gazette, for example, reported as early as December 1789 that a deputation of free coloured citizens was 'admitted at the bar' as 'the cry of liberty had extended to their hemisphere. The tone of southern papers such as Charleston's City Gazette (South Carolina) was entirely different: it warned that ' $\mathrm{t}$ ] he rage for tumult and insurrection diffused through all the French West-India Islands, has infected the free mulattoes of St. Domingo'. According to the SouthCarolinian journalist, the effects of raising coloured people to the status of whites would be disastrous and terminate in 'the total dissolution of the civil bonds which must necessarily correct and unite all ranks once compacted in the state of society!' Yet for all the difference in tone and evaluation, both commentaries mentioned that the free coloureds were "[i]nstructed by the declaration of the rights of man and citizens' (New-YorkDaily Gazette) and 'attempting to discuss the rights of mankind and all constitutional questions' (Charleston City Gazette). From the very beginning, then, from New York City to Charleston, efforts of Saint-Domingue free coloured people to obtain equal citizenship were interpreted through the lens of the applicability of rights declarations within the realm of the colonial empire. ${ }^{48}$

In revolutionary France, while the spokesmen of the gens de couleur and the Société des Amis des Noirs invoked the logic and authority of the Declaration of the Rights of Man and Citizen, the defenders in France of a colonial hierarchy based on skin colour denied free people of colour full civil and political rights.

46 M. Sinha, The Slave's Cause. A History of Abolition (New Haven, Co: Yale University Press, 2017), p. 90.

47 Guyatt, Bind Us Apart.

48 New-York Daily Gazette (New York, New York), December 25, 1789; The City Gazette, Or The Daily Advertiser (Charleston, South Carolina), November 22, 1790. 
They did not argue that the latter lacked the capacities to justifiably claim and exercise the rights of citizenship, but rather used the more indirect reasoning that the Declaration's principles were overall inapplicable to a colonial society that differed so much from the mother country. This view was expressed most clearly by Antoine Barnave, chair of a special Colonial Committee set up by the National Assembly in March 1790:49

Whether we consider them in their interior, or examine the relationships which tie them to the metropolis, we feel that the rigorous and universal application of general principles cannot be suitable [for the colonies]. In the specific case we have to examine, the difference in places, mores, climate, and products seemed to us to require a difference in laws, relations of interest, and position between France and her colonies, [they] do not have the same nature as those that tie the French provinces to either the national body, or with each other, the political relations between them have to differ as well; and we do not believe that the colonies could be included in the constitution that is ordained for the kingdom. ${ }^{50}$

Earlier, Gouy d'Arcy, an influential Saint-Domingue deputy, had equally emphasized the special status of colonies, stressing that 'Saint-Domingue should not be compared to the provinces of the kingdom. The colony is distant; it is isolated; the soil, the inhabitants, modes of cultivation, sources of wealth, everything there is different'.51 Likewise, deputy Jean-Baptiste Nairac from the port city of Bordeaux insisted in that same debate that 'the colonies should not be considered a part of the patrie' but as 'dependencies of it'.52 Since the balance of power in the National Assembly was still heavily on the side of the plantation class during this early phase of the revolution, the Colonial Committee's view won the National Assembly's vote. The decree passed on March 8,1790 , explicitly excluded the colonies from the constitution and left the authority to decide over internal political affairs, including the issue of citizenship, within the hands of white planters. ${ }^{53}$

49 On the committee, see V. Quinney, 'The Problem of Civil Rights for Free Men of Color in the Early French Revolution', French Historical Studies 7 (1972), pp. 544-557.

50 $\quad A P 12$ (8 March 1790), p. 71.

$5^{1} \quad A P 8$ (3 July 1789), p. 188. Also quoted in Popkin, 'The French Revolution's Other Island', at p. 202.

$5^{2} \quad A P 8$ (4 July 1789), p. 189. Also cited in Popkin, 'The French Revolution's Other Island', p. 202.

53 Dubois, Avengers of the New World, pp. 84-85. 
The decree of March 1790, however, left unspecified who would be granted the status of citizens. In October and November 1790, both Grégoire and Brissot published pamphlets attacking the decree as contradicting the 'eternal rights of man'. According to Grégoire, the free people of colour must be considered 'an integral part of the French empire, and accordingly must be citizens'. ${ }^{4}$ Around the same time, one of the leaders of the free coloured people, Vincent Ogé, secretly returned to the colony where he arrived in October1790. Ogé assembled an army and demanded that free coloured people were given full citizenship rights without distinction. Ogé's army, however, was soon crushed. On February 6, 1791, Ogé was tortured to death, his follower who were not able to flee publicly executed. When news reached France of the white planters' ruthless execution of the coloured rebel Vincent Ogé, public opinion and the general political tide began to turn against the increasingly radicalized planters. After a heated debate in May 1791, a majority within the National Assembly decided to grant full citizenship to a limited number of free men of colour born of free property-owning parents.

A significant outcome of these early debates was that members of the Société des Amis des Noirs and their allies became adamant in insisting that the French colonies be considered as an integral part of one, indivisible French republic. The cause of the free people of colour had become another element in the revolutionary regeneration of France and its colonial empire. ${ }^{55}$ When on 15 May, 1791, citizenship was granted to all people of colour born of free parents, the Abbé Grégoire exclaimed in his June 1791 Lettre aux citoyens de couleur et nègres libres de Saint-Domingue et des autres isles françoises de l'Amérique (Letter to the Citizens of Colour and Free Negroes of Saint-Domingue and the other French Islands of America): 'Friends! You were men; - you are now citizens'. Grégoire had shaken off his former nationally confined outlook and instead told his coloured friends that '[t]he resurrection of the French empire opened your hearts to hope. He furthermore removed all remaining doubts about the dependency and direction of influence between France and her colonies. 'It is we', Grégoire made clear, 'who, at the distance of two thousand leagues from you, have been constrained to protect these children'.56 Continuing his self-congratulatory tone he mentioned that 'we please ourselves in the

54 Henri Grégoire, Lettre aux philantropes sur les malheurs, les droits et les réclamations des gens de couleur de Saint Domingue et des autres îles françoises de l'Amérique (Paris, October 1790), pp. 1, 9 .

55 Dubois, Avengers of the New World, p. 196.

$56 \quad$ H. Grégoire, Lettre aux citoyens de couleur et nègres libres de Saint-Domingue et des autres isles françoises de l'Amérique (Paris: Imprimerie du Patriote Français, 1791), pp. 1-2 (emphasis in original). 
belief, that our decree will draw the bands still closer which unite you to the metropole'. French citizenship, however, required absolute loyalty: 'If you act unfaithfully to France, you will be the basest and most abandoned of the human race'. Hence, future generations had to be instructed carefully: 'Devotedly obedient to the laws, teach your children to hold them in high esteem [...] so shall you prepare for the succeeding generation virtuous citizens, public men, and defenders of their country!' Citizenship was to be seen as a gift from 'la mère-patrie', as Grégoire urged them to take your children to 'your shores', 'point their gaze to France' and tell them that 'from thence we have received liberty, justice, and happiness.'57

The decree granting citizenship to free people of colour, although it left slavery untouched, presented a vision of equality and citizenship. The French 'imperial' revolution of 1789 and mid-1791 expanded the agenda of the equality of the rights of man. In the following years it would encourage abolitionist Americans and anti-slavery activists who thought their own revolution was still unfinished to imagine themselves being part of a larger, universalistic emancipation project.

It also did not take long for a reaction to come forth against such emancipation rhetoric. In mid-July 1791 American newspaper readers in New York, Massachusetts, Rhode Island, Connecticut, and elsewhere could read about Edmund Burke's scathing charges filed in late April and early May 1791 against the French National Assembly. The occasion was the debate in the British House of Commons over the Quebec Bill concerning the constitutional government of Canada (which had come under British rule after the Seven Year's War). Saint-Domingue figured prominently in Burke's speech. The debate, a significant moment in the split at the heart of the Whig opposition between Burke and Charles James Fox, was widely reported in the American press. ${ }^{58} \mathrm{On}$ several occasions, Fox had publicly expressed his admiration for the French Revolution. He even suggested that the former French colony of Canada might best be offered a version of the French constitution. In his reply, Burke brought up 'as an instance of the effects of the Rights of Man [...] the sad condition of the French West-India Islands, since the importation of the Parisian frenzy into that quarter of the world'. Burke described the spread of revolutionary

57 Grégoire, Lettre aux citoyens de couleur, pp. 11, 14.

58 The report of the debate appeared in newspapers in New York, Massachusetts, Rhode Island, and Connecticut. The Daily Advertiser (New York, New York), July 16, 1791; Columbian Centinel (Boston, Massachusetts), July 16, 1791; The Providence Gazette and Country Journal (Providence, Rhode Island), July 23, 1791; Connecticut Courant (Hartford, Connecticut), July 25, 1791. For background, see R. Bourke, Empire and Revolution. The Political Life of Edmund Burke (Princeton, N.J.: Princeton University Press, 2015), pp. 763-767. 
principles in the colonies in terms of the infectious zeal of the French: 'The fatal venom of democracy infected every breast; the Free Men and Slaves, the Blacks, the Whites, the Party Coloured inhabitants partook alike of the dire phrensy'. The island was 'thrown into confusion and ruinous disorder' by 'the new principles which had fermented in the giddy brains of the mother country'. Whereas Burke expressed his admiration of the republican government in the newly independent United States, he dismissed the French 'pretended Republican government' as a 'mad democracy' the principles of which 'entered into the colonies opening up 'Pandora's box'.59 Such language, relating 'French' conceptions of democracy to the free coloured people and black slaves who were 'infected' by it, and the 'sad condition' of Saint-Domingue would become a mainstay in the argumentative arsenal of American conservative and proslavery critics of France's imperial revolution. For these critics, the massive slave insurrection that erupted in August 1791 and the events that followed confirmed Burke's warning for the opening up of Pandora's box. For those Frenchmen, Americans, and Dutchmen who supported the expansion of citizenship to free coloured people, the question of revolting black slaves generated a whole new set of considerations.

59 The Daily Advertiser (New York, New York), July 16, 1791 (italic in original). 